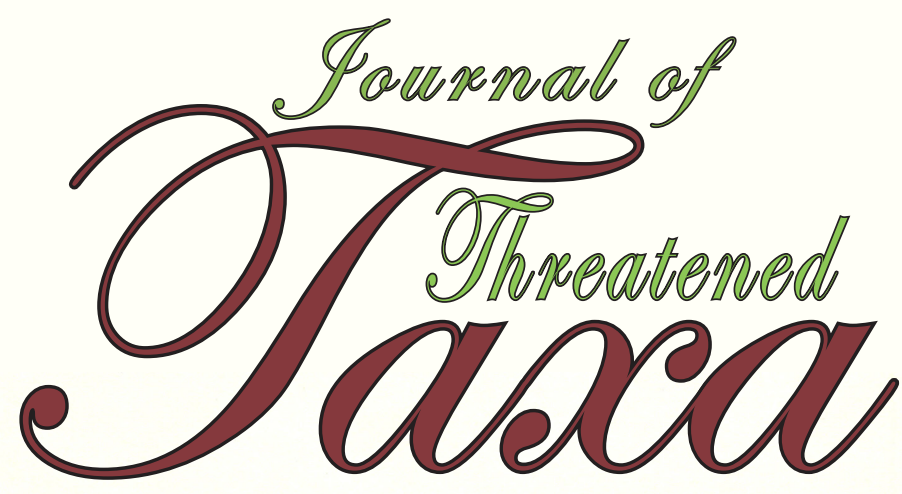

10.11609/jott.2021.13.14.20143-20310 enever.threatenedtaxa.org

26 December 2021 (Online \& Print) Val. 13 | Na. 14 | Pages: 20143-20310 155n 0974-7907 (Online) 155n 0974-7893 (Print)

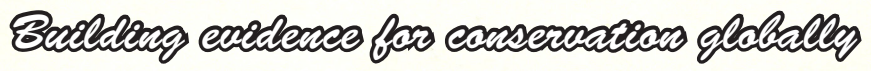

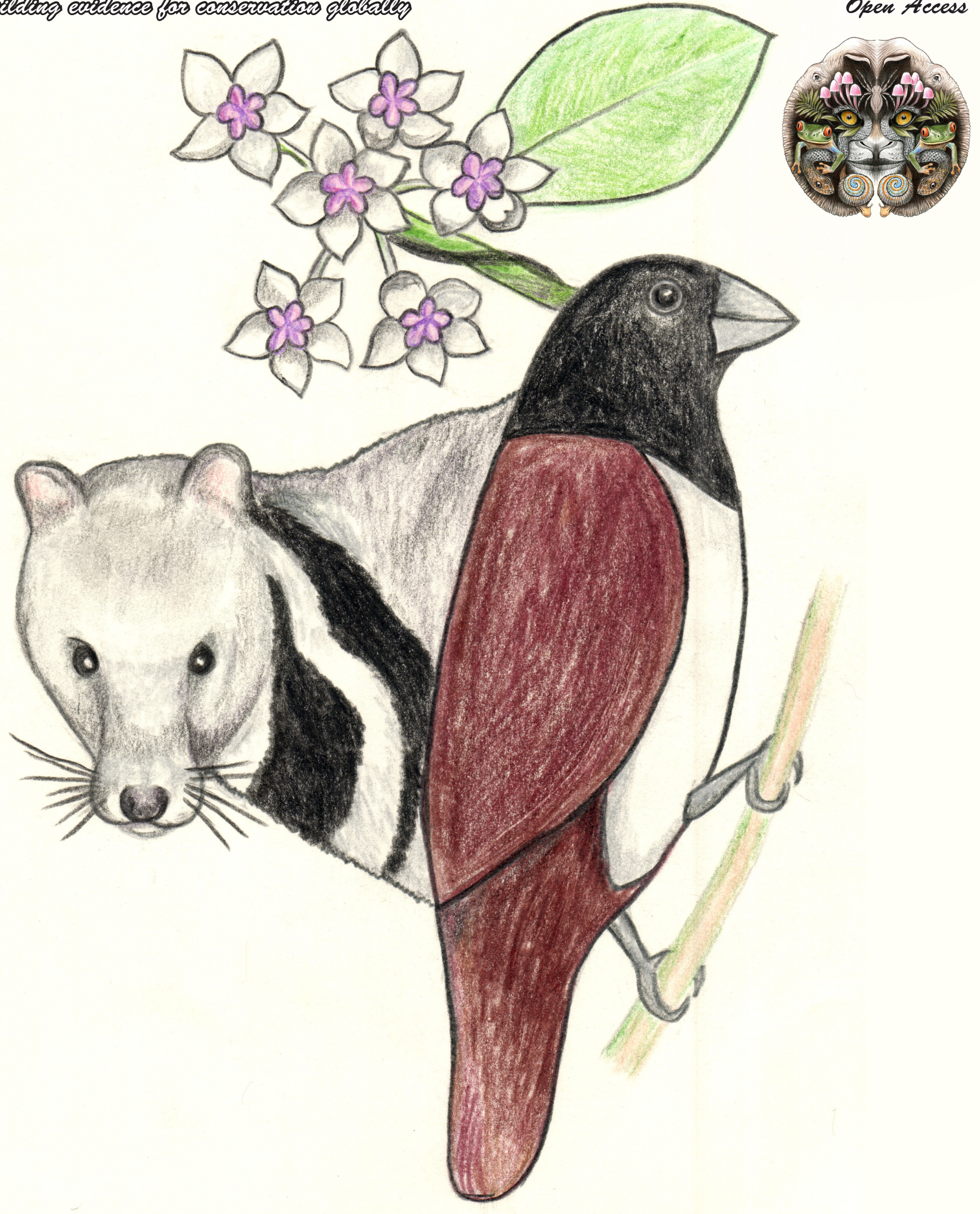

Open Access 


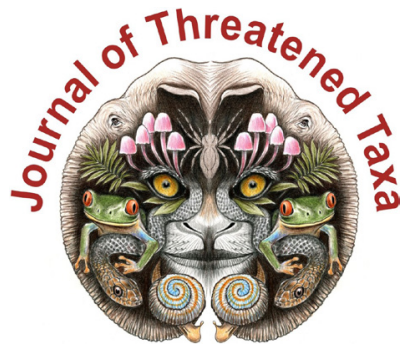

ISSN 0974-7907 (Online); ISSN $0974-7893$ (Print)

Publisher

Host

Wildlife Information Liaison Development Society

www.wild.zooreach.org

Zoo Outreach Organization www.zooreach.org

No. 12, Thiruvannamalai Nagar, Saravanampatti - Kalapatti Road, Saravanampatti, Coimbatore, Tamil Nadu 641035, India

Ph: +91 9385339863 | www.threatenedtaxa.org

Email: sanjay@threatenedtaxa.org

EDITORS

\section{Founder \& Chief Editor}

Dr. Sanjay Molur

Wildlife Information Liaison Development (WILD) Society \& Zoo Outreach Organization (ZOO),

12 Thiruvannamalai Nagar, Saravanampatti, Coimbatore, Tamil Nadu 641035, India

\section{Deputy Chief Editor}

Dr. Neelesh Dahanukar

Noida, Uttar Pradesh, India

\section{Managing Editor}

Mr. B. Ravichandran, WILD/ZOO, Coimbatore, India

\section{Associate Editors}

Dr. Mandar Paingankar, Government Science College Gadchiroli, Maharashtra 442605, India

Dr. Ulrike Streicher, Wildlife Veterinarian, Eugene, Oregon, USA

Ms. Priyanka lyer, ZOO/WILD, Coimbatore, Tamil Nadu 641035, India

Dr. BA. Daniel, $200 / \mathrm{WILD}$, Coimbatore, Tamil Nadu 641035, India

\section{Editorial Board}

Dr. Russel Mittermeie

Executive Vice Chair, Conservation International, Arlington, Virginia 22202, USA

\section{Prof. Mewa Singh Ph.D., FASc, FNA, FNASc, FNAPsy}

Ramanna Fellow and Life-Long Distinguished Professor, Biopsychology Laboratory, and Institute of Excellence, University of Mysore, Mysuru, Karnataka 570006, India; Honorary Professor, Jawaharlal Nehru Centre for Advanced Scientific Research, Bangalore; and Adjunct Professor, National Institute of Advanced Studies, Bangalore

\section{Stephen D. Nash}

Scientific Illustrator, Conservation International, Dept. of Anatomical Sciences, Health Sciences Center, T-8, Room 045, Stony Brook University, Stony Brook, NY 11794-8081, USA

\section{Dr. Fred Pluthero}

Toronto, Canada

\section{Dr. Priya Davidar}

Sigur Nature Trust, Chadapatti, Mavinhalla PO, Nilgiris, Tamil Nadu 643223, India

\section{Dr. Martin Fisher}

Senior Associate Professor, Battcock Centre for Experimental Astrophysics, Cavendish

Laboratory, JJ Thomson Avenue, Cambridge CB3 OHE, UK

\section{Dr. John Fellowes}

Honorary Assistant Professor, The Kadoorie Institute, 8/F, T.T. Tsui Building, The University of Hong Kong, Pokfulam Road, Hong Kong

\section{Prof. Dr. Mirco Solé}

Universidade Estadual de Santa Cruz, Departamento de Ciências Biológicas, Vice-coordenado do Programa de Pós-Graduação em Zoologia, Rodovia Ilhéus/Itabuna, Km 16 (45662-000)

Salobrinho, Ilhéus - Bahia - Brasil

\section{Dr. Rajeev Raghavan}

Professor of Taxonomy, Kerala University of Fisheries \& Ocean Studies, Kochi, Kerala, India

\section{English Editors}

Mrs. Mira Bhojwani, Pune, India

Dr. Fred Pluthero, Toronto, Canad

Mr. P. Ilangovan, Chennai, India

Web Development

Mrs. Latha G. Ravikumar, ZOO/WILD, Coimbatore, India

\section{Typesetting}

Mr. Arul Jagadish, ZOO, Coimbatore, India

Mrs. Radhika, ZOO, Coimbatore, India

Mrs. Geetha, ZOO, Coimbatore India
Fundraising/Communications

Mrs. Payal B. Molur, Coimbatore, India

Subject Editors 2018-2020

Fungi

Dr. B. Shivaraju, Bengaluru, Karnataka, India

Dr. R.K. Verma, Tropical Forest Research Institute, Jabalpur, India

Dr. Vatsavaya S. Raju, Kakatiay University, Warangal, Andhra Pradesh, India

Dr. M. Krishnappa, Jnana Sahyadri, Kuvempu University, Shimoga, Karnataka, India

Dr. K.R. Sridhar, Mangalore University, Mangalagangotri, Mangalore, Karnataka, India

Dr. Gunjan Biswas, Vidyasagar University, Midnapore, West Bengal, India

\section{Plants}

Dr. G.P. Sinha, Botanical Survey of India, Allahabad, India

Dr. N.P. Balakrishnan, Ret. Joint Director, BSI, Coimbatore, India

Dr. Shonil Bhagwat, Open University and University of Oxford, UK

Prof. D.J. Bhat, Retd. Professor, Goa University, Goa, India

Dr. Ferdinando Boero, Università del Salento, Lecce, Italy

Dr. Dale R. Calder, Royal Ontaro Museum, Toronto, Ontario, Canada

Dr. Cleofas Cervancia, Univ. of Philippines Los Baños College Laguna, Philippines

Dr. F.B. Vincent Florens, University of Mauritius, Mauritius

Dr. Merlin Franco, Curtin University, Malaysia

Dr. V. Irudayaraj, St. Xavier's College, Palayamkottai, Tamil Nadu, India

Dr. B.S. Kholia, Botanical Survey of India, Gangtok, Sikkim, India

Dr. Pankaj Kumar, Kadoorie Farm and Botanic Garden Corporation, Hong Kong S.A.R., China

Dr. V. Sampath Kumar, Botanical Survey of India, Howrah, West Bengal, India

Dr. A.J. Solomon Raju, Andhra University, Visakhapatnam, India

Dr. Vijayasankar Raman, University of Mississippi, USA

Dr. B. Ravi Prasad Rao, Sri Krishnadevaraya University, Anantpur, India

Dr. K. Ravikumar, FRLHT, Bengaluru, Karnataka, India

Dr. Aparna Watve, Pune, Maharashtra, India

Dr. Qiang Liu, Xishuangbanna Tropical Botanical Garden, Yunnan, China

Dr. Noor Azhar Mohamed Shazili, Universiti Malaysia Terengganu, Kuala Terengganu, Malaysia

Dr. M.K. Vasudeva Rao, Shiv Ranjani Housing Society, Pune, Maharashtra, India

Prof. A.J. Solomon Raju, Andhra University, Visakhapatnam, India

Dr. Mandar Datar, Agharkar Research Institute, Pune, Maharashtra, India

Dr. M.K. Janarthanam, Goa University, Goa, India

Dr. K. Karthigeyan, Botanical Survey of India, India

Dr. Errol Vela, University of Montpellier, Montpellier, France

Dr. P. Lakshminarasimhan, Botanical Survey of India, Howrah, India

Dr. Larry R. Noblick, Montgomery Botanical Center, Miami, USA

Dr. K. Haridasan, Pallavur, Palakkad District, Kerala, India

Dr. Analinda Manila-Fajard, University of the Philippines Los Banos, Laguna, Philippines

Dr. P.A. Sinu, Central University of Kerala, Kasaragod, Kerala, India

Dr. Afroz Alam, Banasthali Vidyapith (accredited A grade by NAAC), Rajasthan, India

Dr. K.P. Rajesh, Zamorin's Guruvayurappan College, GA College PO, Kozhikode, Kerala, India

Dr. David E. Boufford, Harvard University Herbaria, Cambridge, MA 02138-2020, USA

Dr. Ritesh Kumar Choudhary, Agharkar Research Institute, Pune, Maharashtra, India

Dr. Navendu Page, Wildlife Institute of India, Chandrabani, Dehradun, Uttarakhand, India

\section{Invertebrates}

Dr. R.K. Avasthi, Rohtak University, Haryana, India

Dr. D.B. Bastawade, Maharashtra, India

Dr. Partha Pratim Bhattacharjee, Tripura University, Suryamaninagar, India

Dr. Kailash Chandra, Zoological Survey of India, Jabalpur, Madhya Pradesh, India

Dr. Ansie Dippenaar-Schoeman, University of Pretoria, Queenswood, South Africa

Dr. Rory Dow, National Museum of natural History Naturalis, The Netherlands

Dr. Brian Fisher, California Academy of Sciences, USA

Dr. Richard Gallon, llandudno, North Wales, LL30 1UP

Dr. Hemant V. Ghate, Modern College, Pune, India

Dr. M. Monwar Hossain, Jahangirnagar University, Dhaka, Bangladesh

Mr. Jatishwor Singh Irungbam, Biology Centre CAS, Branišovská, Czech Republic.

Dr. Ian J. Kitching, Natural History Museum, Cromwell Road, UK

Dr. George Mathew, Kerala Forest Research Institute, Peechi, India

For Focus, Scope, Aims, and Policies, visit https://threatenedtaxa.org/index.php/JoTT/aims_scope
For Article Submission Guidelines, visit https://threatenedtaxa.org/index.php/JoTT/about/submissions
For Policies against Scientific Misconduct, visit https://threatenedtaxa.org/index.php/JoTT/policies_various 


\title{
Extended distribution of two endemic epiphytes from the Western Ghats to the Deccan Plateau
}

\author{
Sonali Vishnu Deore ${ }^{1}$ (D), Mangala Dala Sonawane ${ }^{2}$ (i) \& Sharad Suresh Kambale ${ }^{3}$ (1) \\ ${ }^{1}$ Department of Botany, MVP Samaj's, Karmveer Shantaram Bapu Kondaji Wavare (KSKW) College, CIDCO, Nashik, Maharashtra, India. \\ 1,2 PG Department of Botany and Research Centre, MVP Samaj's, KRT Arts, BH Commerce \& AM Science (KTHM) College, Nashik, \\ Maharashtra, India. \\ ${ }^{3}$ Department of Botany, MVP Samaj's, Art's, Commerce \& Science College, Tryambakeshwar, Nashik, Maharashtra 422212, India. \\ ${ }^{1}$ sonalishinde2889@gmail.com (corresponding author), ${ }^{2}$ dr.mdsonawane@yahoo.co.in, ${ }^{3}$ sharad@mvptryambakcollege.ac.in
}

\begin{abstract}
Extended distribution of two endemic epiphytes, viz., Hoya wightii Hook.f. (Apocynaceae) and Bulbophyllum fimbriatum Rchb.f (Orchidaceae) from Western Ghats to Deccan Plateau is reported during field explorations undertaken to document the flora of Kalwan tehsil. The presence of these two species in the Deccan plateau indicates the need of further explorations to document the diversity and endemism of strict endemics of Western Ghats in Deccan plateau.

Keywords: India, Kalwan tehsil, new distribution records, northern Western Ghats, rare plants.
\end{abstract}

Forests are categorized according to the plant species present in a particular area, which in turn depends upon the environmental conditions prevalent in that area. Similarly, the plant species occurring in a particular area are important in deciding the type of forest present in that area. Forest in Kalwan tehsil has been shown to fall in moist tropical and dry tropical by Lakshminarasimhan \& Sharma (1991). From the available literature it is evident that much focus has been given on Markanday hill top and Saptashrungi Fort while remaining area of Kalwan tehsil has been scarcely mentioned in the previous works. Therefore, explorations carried out to study the floristic wealth of less explored areas of
Kalwan tehsil from ethno-botanical perspective. During these explorations, two epiphytes, viz., Hoya wightii Hook.f. (Apocynaceae) and Bulbophyllum fimbriatum Rchb.f. (Orchidaceae) were observed. These species were supposedly endemic to Western Ghats (Pande et al. 2010; Singh et al. 2015) and never been reported from Deccan Plateau. After analysis it is found that, these species have extended their distribution to the Deccan plateau (Figure 1). Their description is provided, the map is given and notes on distribution are also provided.

\section{Material AND Methods}

Field trips were carried out to explore floristic wealth and record the ethno-botanically important plants of Kalwan tehsil. Plants were photographed, collected, and herbarium specimens were prepared as per Jain \& Rao (1971). Plants were identified by using local floras (Sharma et al. 1996; Singh et al. 2001). The map is as per Rodgers \& Panwar (1988).

\section{Study area}

Kalwan tehsil is located in the northwestern part of Nashik District in Maharashtra state of India, between

Citation: Deore, S.V., M.D. Sonawane \& S.S. Kambale (2021). Extended distribution of two endemic epiphytes from the Western Ghats to the Deccan Plateau. Journal of Threatened Taxa 13(14): 20258-20260. https://doi.org/10.11609/jott.7598.13.14.20258-20260

Copyright: (C) Deore et al. 2021. Creative Commons Attribution 4.0 International License. JoTT allows unrestricted use, reproduction, and distribution of this article in any medium by providing adequate credit to the author(s) and the source of publication.

Funding: Self-funded.

Competing interests: The authors declare no competing interests.

Acknowledgements: The authors thank the principals of their respective colleges for necessary facilities. Authors thank Dr. C. Sudhakar Reddy for providing the map of the Western Ghats. 


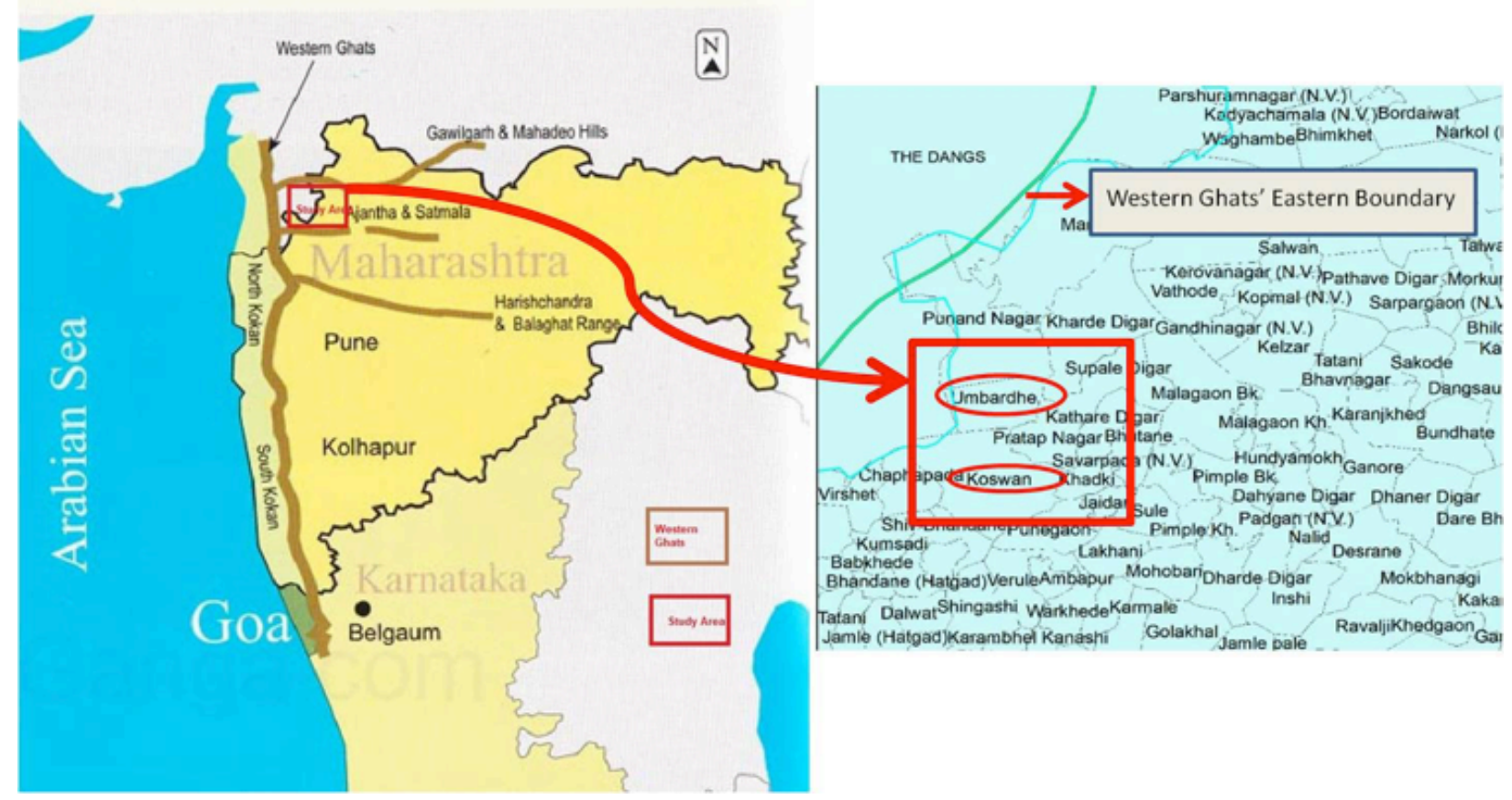

Figure 1. Collection localities of Hoya wightii Hook.f. and Bulbophyllum fimbriatum Rchb.f. from Deccan Plateau.

$20^{\circ} 29^{\prime} 25^{\prime \prime} \mathrm{N}$ Latitude and $74^{\circ} 01^{\prime} 35^{\prime \prime} \mathrm{E}$ Longitude. It is bordered by Dang district of Gujarat state towards west, Baglan tehsil Nashik district towards the north, Deola towards east and Chandwad and Dindori tehsils towards the south.

\section{RESULTS}

Hoya wightii Hook.f. Fl. Brit. India 4: 59 (1883)

(Image 1A)

Epiphytic pendulous climbers. Stems smooth, cylindrical with adventitious roots at regular intervals. Leaves opposite, petiolate, elliptic lanceolate, acuminate at apex, narrow at base. Flowers in lateral umbellate cymes. Corolla cream coloured, rotate; petals united in the lower halves, slightly pubescent within. Staminal corona purple. Follicles linear to cylindrical.

Phenology: Flowering and Fruiting: May-January.

Notes: Found growing on Mangifera indica L. and Ficus racemosa $\mathrm{L}$.

Specimens examined: SVD-270620211, 27.vi.2021, India, Maharashtra, Nashik district, Kalwan tehsil, Koswan, coll. S.V. Deore \& M.D. Sonawane (Western Circle, BSI, Pune), Image 2.

Distribution: Goa, Karnataka, Kerala, Maharashtra, and Tamil Nadu. The present record is the northernmost distribution of this species from Deccan Plateau.

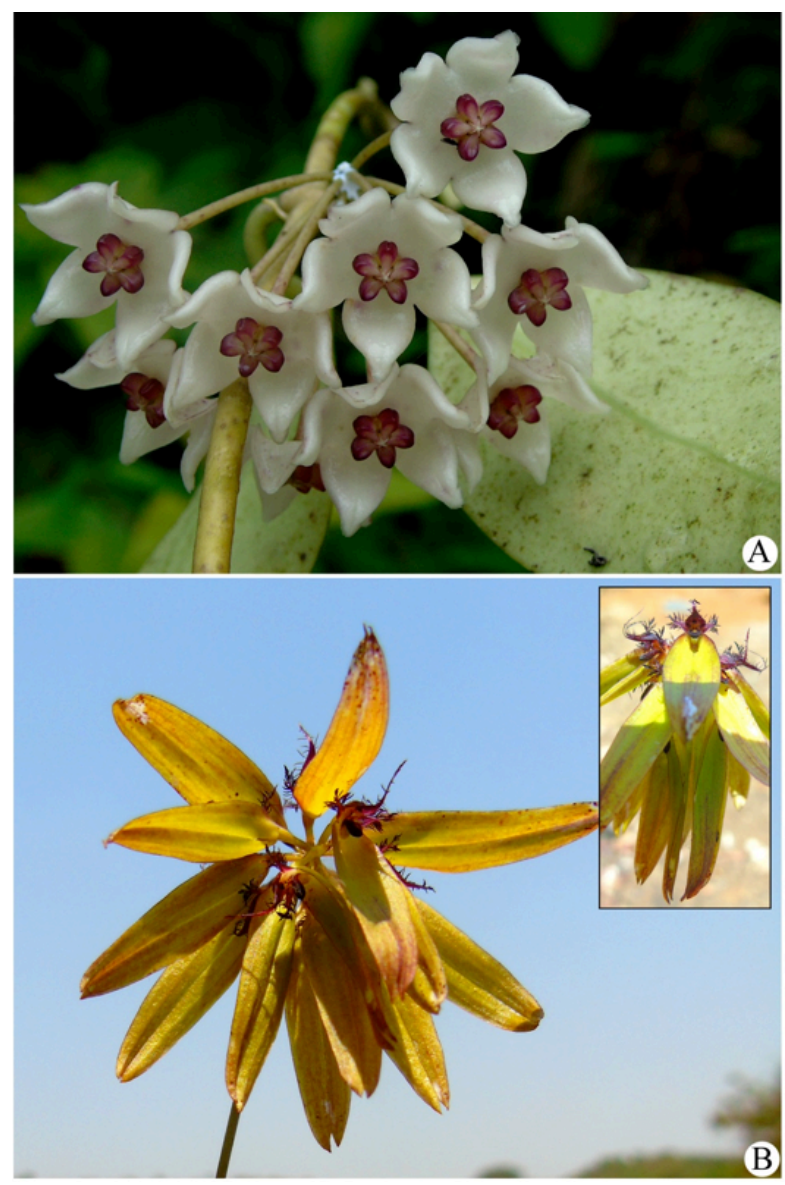

Image 1. A-Hoya wightii Hook.f. | B-Bulbophyllum fimbriatum Rchb.f. (C) Sonali Deore. 


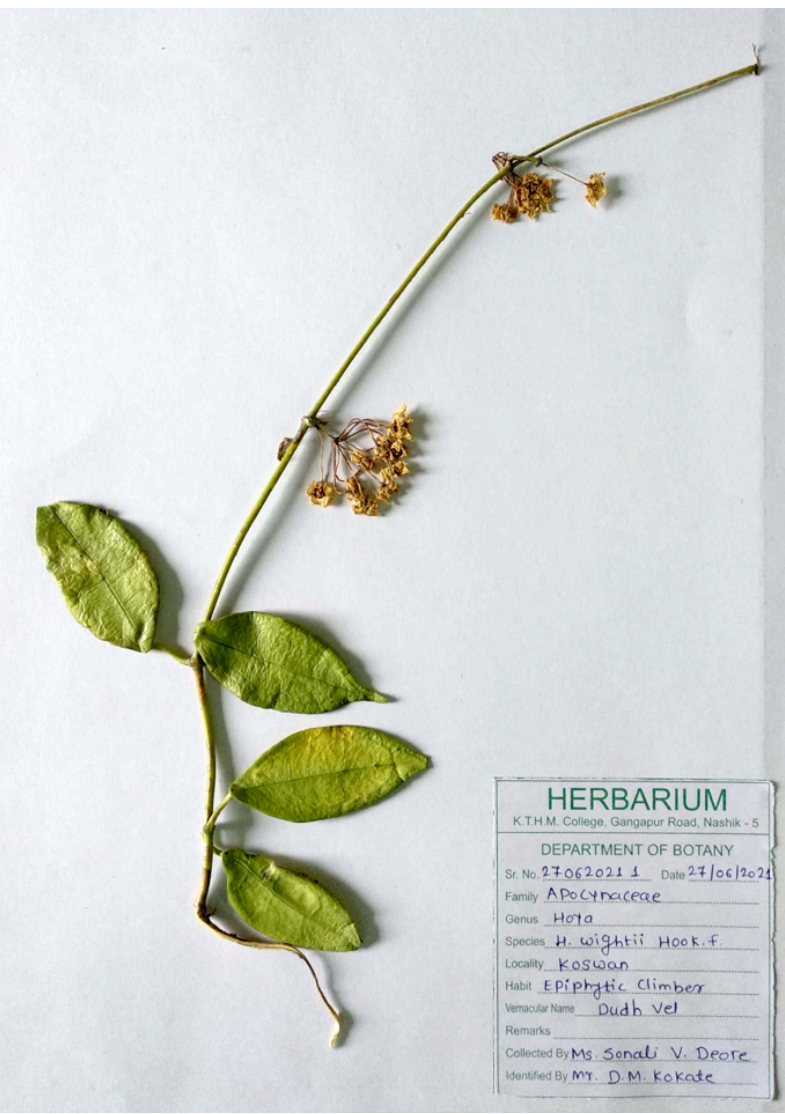

Image 2. Herbarium of Hoya wightii Hook.f.

Bulbophyllum fimbriatum (Lindl) Rchb.f. Ann. Bot. Syst. (Walpers) 6(2): 260 (1861) (Image 1B)

Rhizome stout, pseudobulbs sub-globose, about 1.5 to $2 \mathrm{~cm}$ long. Leaves altering with flowering, up to 5-12 $\times 2 \mathrm{~cm}$. Flowers greenish-yellow, lateral sepals much longer than the dorsal ones, lip spathulate, fleshy, recurved. Capsules green, ob-pyriform, $1 \times 0.5 \mathrm{~cm}$.

Phenology: Flowering and Fruiting. February-March.

Specimens examined: SVD-280320211, 28.iii.2021, India, Maharashtra, Nashik district, Kalwan tehsil, Umbardhe, coll. S.V. Deore \& M.D. Sonawane (Western Circle, BSI, Pune), Image 3.

Notes: Found growing on Mangifera indica L.

Distribution: Kiruthika et al. (2018) reported this species from Gadalur (Tamil Nadu). In Maharashtra it has been reported (Sharma et al. 1996) from Pune Satara and Sindhudurg districts. It has not been reported from Nashik district (Lakshminarasimhan \& Sharma 1991; Yadav \& Dhanke 2010) previously. It was strictly

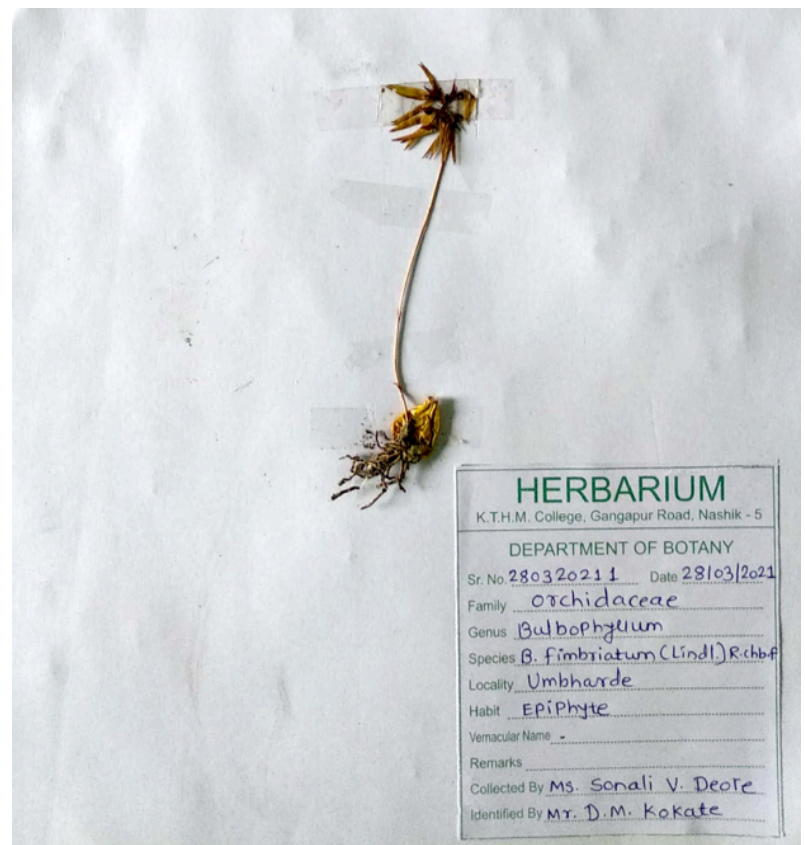

Image 3. Herbarium of Bulbophyllum fimbriatum Rchb.f.

endemic to Western Ghats (Singh \& Singh (2015) and now extended its distribution to Deccan Plateau.

\section{REFERENCES}

Jain, S.K. \& R.R. Rao (1977). A Handbook of Field and Herbarium Methods. Today \& Tomorrow's Printers \& Publishers, 157 pp.

Kiruthika, K., M. Sulaiman, P.B. Harathi \& R. Gopalan (2018). Revelatory notes on Bulbophyllum fimbriatum - An Endemic orchid of Western Ghats, India. Journal of Economic and Taxonomic Botany 42: 65-69.

Lakshminarasimhan, P. \& B.D. Sharma (1991). Flora of Nasik District. Botanical Survey of India, $644 \mathrm{pp}$.

Pande, S., N. Sant, V. Vishwasrao \& M.N. Datar (2010). Wild Orchids of Northern Western Ghats: Including Maharashtra, Goa and Belgaum. Ela Foundation.

Rodgers, W.A. \& H.S. Panwar (1988). Planning a Wildlife Protected Area Network in India. Wildlife Institute of India, Dehradun.

Sharma, B.D., S. Karthikeyan \& N.P. Singh (1996). Flora of Maharashtra Monocotyledons. Botanical Survey of India, $792 \mathrm{pp}$.

Singh, J.J. \& P. Singh (2015). Threatened orchids of Maharashtra - a preliminary assessment based on IUCN regional guidelines and conservation prioritization. Journal of Orchid Society of India 29: $1-14$.

Singh, N.P., P. Lakshminarasimhan, S. Karthikeyan \& P.V. Prasanna (2001). Flora of Maharashtra State Dicotyledones, Vol. 2 Botanical Survey of India, $1080 \mathrm{pp}$.

Singh, P., K. Karthigeyan, P. Lakshminarasimhan \& S.S. Dash (2015). Endemic vascular plants of India. Botanical Survey of India.

Yadav, S. \& P.V. Dhanke (2010). A Checklist of Plants of Nashik District. Nashik Forest Circle, Nashik, 143 pp. 

Dr. John Noyes, Natural History Museum, London, UK

Dr. Albert G. Orr, Griffith University, Nathan, Australia

Dr. Sameer Padhye, Katholieke Universiteit Leuven, Belgium

Dr. Nancy van der Poorten, Toronto, Canada

Dr. Kareen Schnabel, NIWA, Wellington, New Zealand

Dr. R.M. Sharma, (Retd.) Scientist, Zoological Survey of India, Pune, India

Dr. Manju Siliwal, WILD, Coimbatore, Tamil Nadu, India

Dr. G.P. Sinha, Botanical Survey of India, Allahabad, India

Dr. K.A. Subramanian, Zoological Survey of India, New Alipore, Kolkata, India

Dr. P.M. Sureshan, Zoological Survey of India, Kozhikode, Kerala, India

Dr. R. Varatharajan, Manipur University, Imphal, Manipur, India

Dr. Eduard Vives, Museu de Ciències Naturals de Barcelona, Terrassa, Spain

Dr. James Young, Hong Kong Lepidopterists' Society, Hong Kong

Dr. R. Sundararaj, Institute of Wood Science \& Technology, Bengaluru, India

Dr. M. Nithyanandan, Environmental Department, La Ala Al Kuwait Real Estate. Co. K.S.C.,

Kuwait

Dr. Himender Bharti, Punjabi University, Punjab, India

Mr. Purnendu Roy, London, UK

Dr. Saito Motoki, The Butterfly Society of Japan, Tokyo, Japan

Dr. Sanjay Sondhi, TITLI TRUST, Kalpavriksh, Dehradun, India

Dr. Nguyen Thi Phuong Lien, Vietnam Academy of Science and Technology, Hanoi, Vietnam

Dr. Nitin Kulkarni, Tropical Research Institute, Jabalpur, India

Dr. Robin Wen Jiang Ngiam, National Parks Board, Singapore

Dr. Lional Monod, Natural History Museum of Geneva, Genève, Switzerland.

Dr. Asheesh Shivam, Nehru Gram Bharti University, Allahabad, India

Dr. Rosana Moreira da Rocha, Universidade Federal do Paraná, Curitiba, Brasi

Dr. Kurt R. Arnold, North Dakota State University, Saxony, Germany

Dr. James M. Carpenter, American Museum of Natural History, New York, USA

Dr. David M. Claborn, Missouri State University, Springfield, USA

Dr. Kareen Schnabel, Marine Biologist, Wellington, New Zealand

Dr. Amazonas Chagas Júnior, Universidade Federal de Mato Grosso, Cuiabá, Brasil

Mr. Monsoon Jyoti Gogoi, Assam University, Silchar, Assam, India

Dr. Heo Chong Chin, Universiti Teknologi MARA (UiTM), Selangor, Malaysia

Dr. R.J. Shiel, University of Adelaide, SA 5005, Australia

Dr. Siddharth Kulkarni, The George Washington University, Washington, USA

Dr. Priyadarsanan Dharma Rajan, ATREE, Bengaluru, India

Dr. Phil Alderslade, CSIRO Marine And Atmospheric Research, Hobart, Australia

Dr. John E.N. Veron, Coral Reef Research, Townsville, Australia

Dr. Daniel Whitmore, State Museum of Natural History Stuttgart, Rosenstein, Germany.

Dr. Yu-Feng Hsu, National Taiwan Normal University, Taipei City, Taiwan

Dr. Keith V. Wolfe, Antioch, California, USA

Dr. Siddharth Kulkarni, The Hormiga Lab, The George Washington University, Washington,

D.C., USA

Dr. Tomas Ditrich, Faculty of Education, University of South Bohemia in Ceske

Budejovice, Czech Republic

Dr. Mihaly Foldvari, Natural History Museum, University of Oslo, Norway

Dr. V.P. Uniyal, Wildlife Institute of India, Dehradun, Uttarakhand 248001, India

Dr. John T.D. Caleb, Zoological Survey of India, Kolkata, West Bengal, India

Dr. Priyadarsanan Dharma Rajan, Ashoka Trust for Research in Ecology and the Environment

(ATREE), Royal Enclave, Bangalore, Karnataka, India

\section{Fishes}

Dr. Neelesh Dahanukar, IISER, Pune, Maharashtra, India

Dr. Topiltzin Contreras MacBeath, Universidad Autónoma del estado de Morelos, México

Dr. Heok Hee Ng, National University of Singapore, Science Drive, Singapore

Dr. Rajeev Raghavan, St. Albert's College, Kochi, Kerala, India

Dr. Robert D. Sluka, Chiltern Gateway Project, A Rocha UK, Southall, Middlesex, UK

Dr. E. Vivekanandan, Central Marine Fisheries Research Institute, Chennai, India

Dr. Davor Zanella, University of Zagreb, Zagreb, Croatia

Dr. A. Biju Kumar, University of Kerala, Thiruvananthapuram, Kerala, India

Dr. Akhilesh K.V., ICAR-Central Marine Fisheries Research Institute, Mumbai Research

Centre, Mumbai, Maharashtra, India

Dr. J.A. Johnson, Wildlife Institute of India, Dehradun, Uttarakhand, India

Amphibians

Dr. Sushil K. Dutta, Indian Institute of Science, Bengaluru, Karnataka, India

Dr. Annemarie Ohler, Muséum national d'Histoire naturelle, Paris, France

\section{Reptiles}

Dr. Gernot Vogel, Heidelberg, Germany

Dr. Raju Vyas, Vadodara, Gujarat, India

Dr. Pritpal S. Soorae, Environment Agency, Abu Dubai, UAE.

Prof. Dr. Wayne J. Fuller, Near East University, Mersin, Turkey

Prof. Chandrashekher U. Rivonker, Goa University, Taleigao Plateau, Goa. India

Dr. S.R. Ganesh, Chennai Snake Park, Chennai, Tamil Nadu, India

Dr. Himansu Sekhar Das, Terrestrial \& Marine Biodiversity, Abu Dhabi, UAE
Birds

Dr. Hem Sagar Baral, Charles Sturt University, NSW Australia

Dr. Chris Bowden, Royal Society for the Protection of Birds, Sandy, UK

Dr. Priya Davidar, Pondicherry University, Kalapet, Puducherry, India

Dr. J.W. Duckworth, IUCN SSC, Bath, UK

Dr. Rajah Jayapal, SACON, Coimbatore, Tamil Nadu, India

Dr. Rajiv S. Kalsi, M.L.N. College, Yamuna Nagar, Haryana, India

Dr. V. Santharam, Rishi Valley Education Centre, Chittoor Dt., Andhra Pradesh, India

Dr. S. Balachandran, Bombay Natural History Society, Mumbai, India

Mr. J. Praveen, Bengaluru, India

Dr. C. Srinivasulu, Osmania University, Hyderabad, India

Dr. K.S. Gopi Sundar, International Crane Foundation, Baraboo, USA

Dr. Gombobaatar Sundev, Professor of Ornithology, Ulaanbaatar, Mongolia

Prof. Reuven Yosef, International Birding \& Research Centre, Eilat, Israel

Dr. Taej Mundkur, Wetlands International, Wageningen, The Netherlands

Dr. Carol Inskipp, Bishop Auckland Co., Durham, UK

Dr. Tim Inskipp, Bishop Auckland Co, Durham, UK

Dr. V. Gokula, National College, Tiruchirappalli, Tamil Nadu, India

Dr. Arkady Lelej, Russian Academy of Sciences, Vladivostok, Russia

Dr. Simon Dowell, Science Director, Chester Zoo, UK

Dr. Mário Gabriel Santiago dos Santos, Universidade de Trás-os-Montes e Alto Douro,

Quinta de Prados, Vila Real, Portugal

Dr. Grant Connette, Smithsonian Institution, Royal, VA, USA

Dr. M. Zafar-ul Islam, Prince Saud Al Faisal Wildlife Research Center, Taif, Saudi Arabia

Mammals

Dr. Giovanni Amori, CNR - Institute of Ecosystem Studies, Rome, Italy

Dr. Anwaruddin Chowdhury, Guwahati, India

Dr. David Mallon, Zoological Society of London, UK

Dr. Shomita Mukherjee, SACON, Coimbatore, Tamil Nadu, India

Dr. Angie Appel, Wild Cat Network, Germany

Dr. P.O. Nameer, Kerala Agricultural University, Thrissur, Kerala, India

Dr. Ian Redmond, UNEP Convention on Migratory Species, Lansdown, UK

Dr. Heidi S. Riddle, Riddle's Elephant and Wildlife Sanctuary, Arkansas, USA

Dr. Karin Schwartz, George Mason University, Fairfax, Virginia.

Dr. Lala A.K. Singh, Bhubaneswar, Orissa, India

Dr. Mewa Singh, Mysore University, Mysore, India

Dr. Paul Racey, University of Exeter, Devon, UK

Dr. Honnavalli N. Kumara, SACON, Anaikatty P.O., Coimbatore, Tamil Nadu, India

Dr. Nishith Dharaiya, HNG University, Patan, Gujarat, India

Dr. Spartaco Gippoliti, Socio Onorario Società Italiana per la Storia della Fauna "Giuseppe

Altobello", Rome, Italy

Dr. Justus Joshua, Green Future Foundation, Tiruchirapalli, Tamil Nadu, India

Dr. H. Raghuram, The American College, Madurai, Tamil Nadu, India

Dr. Paul Bates, Harison Institute, Kent, UK

Dr. Jim Sanderson, Small Wild Cat Conservation Foundation, Hartford, USA

Dr. Dan Challender, University of Kent, Canterbury, UK

Dr. David Mallon, Manchester Metropolitan University, Derbyshire, UK

Dr. Brian L. Cypher, California State University-Stanislaus, Bakersfield, CA

Dr. S.S. Talmale, Zoological Survey of India, Pune, Maharashtra, India

Prof. Karan Bahadur Shah, Budhanilakantha Municipality, Kathmandu, Nepal

Dr. Susan Cheyne, Borneo Nature Foundation International, Palangkaraja, Indonesia

Dr. Hemanta Kafley, Wildlife Sciences, Tarleton State University, Texas, USA

\section{Other Disciplines}

Dr. Aniruddha Belsare, Columbia MO 65203, USA (Veterinary)

Dr. Mandar S. Paingankar, University of Pune, Pune, Maharashtra, India (Molecular)

Dr. Jack Tordoff, Critical Ecosystem Partnership Fund, Arlington, USA (Communities)

Dr. Ulrike Streicher, University of Oregon, Eugene, USA (Veterinary)

Dr. Hari Balasubramanian, EcoAdvisors, Nova Scotia, Canada (Communities)

Dr. Rayanna Hellem Santos Bezerra, Universidade Federal de Sergipe, São Cristóvão, Brazil

Dr. Jamie R. Wood, Landcare Research, Canterbury, New Zealand

Dr. Wendy Collinson-Jonker, Endangered Wildlife Trust, Gauteng, South Africa

Dr. Rajeshkumar G. Jani, Anand Agricultural University, Anand, Gujarat, India

Dr. O.N. Tiwari, Senior Scientist, ICAR-Indian Agricultural Research Institute (IARI), New

Delhi, India

Dr. L.D. Singla, Guru Angad Dev Veterinary and Animal Sciences University, Ludhiana, India

Dr. Rupika S. Rajakaruna, University of Peradeniya, Peradeniya, Sri Lanka

Dr. Bahar Baviskar, Wild-CER, Nagpur, Maharashtra 440013, India

Reviewers 2018-2020

Due to pausity of space, the list of reviewers for $2018-2020$ is available online.

The opinions expressed by the authors do not reflect the views of the Journal of Threatened Taxa, Wildlife Information Liaison Development Society, Zoo Outreach Organization, or any of the partners. The journal, the publisher, the host, and the partners are not responsible for the accuracy of the political boundaries shown in the maps by the authors.

Journal of Threatened Taxa is indexed/abstracted in Bibliography of Systematic Mycology, Biological Abstracts, BIOSIS Previews, CAB Abstracts, EBSCO, Google Scholar, Index Copernicus, Index Fungorum, JournalSeek, National Academy of Agricultural Sciences, NewJour, OCLC WorldCat, SCOPUS, Stanford University Libraries, Virtual Library of Biology, Zoological Records.

NAAS rating (India) 5.64
Print copies of the Journal are available at cost. Write to:

The Managing Editor, JoTT,

c/o Wildlife Information Liaison Development Society,

No. 12, Thiruvannamalai Nagar, Saravanampatti - Kalapatti Road,

Saravanampatti, Coimbatore, Tamil Nadu 641035, India

ravi@threatenedtaxa.org 


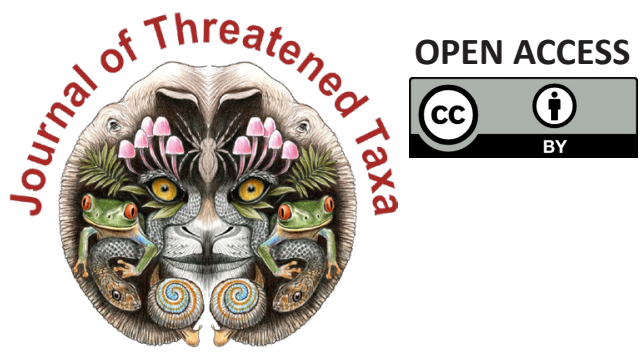

www.threatenedtaxa.org

The Journal of Threatened Taxa (JoTT) is dedicated to building evidence for conservation globally by publishing peer-reviewed articles online every month at a reasonably rapid rate at www.threatenedtaxa.org. All articles published in JoTT are registered under Creative Commons Attribution 4.0 International License unless otherwise mentioned. JoTT allows allows unrestricted use, reproduction, and distribution of articles in any medium by providing adequate credit to the author(s) and the source of publication.

\section{ISSN $0974-7907$ (Online) | ISSN $0974-7893$ (Print)}

\section{December 2021 | Vol. 13 | No. 14 | Pages: 20143-20310 \\ Date of Publication: 26 December 2021 (Online \& Print) DOI: 10.11609/jott.2021.13.14.20143-20310}

\section{Communications}

Updated distribution of seven Trichosanthes L. (Cucurbitales: Cucurbitaceae) taxa in India, along with taxonomic notes

Kanakasabapathi Pradheep, Soyimchiten, Ganjalagatta Dasaiah Harish, Muhammed Abdul Nizar, Kailash Chandra Bhatt, Anjula Pandey \& Sudhir Pal Ahlawat, Pp. 20143-20152

Dragonflies and Damselflies (Insecta: Odonata) of Aryanad Grama Panchayat, Kerala, India

- Reji Chandran \& A. Vivek Chandran, Pp. 20153-20166

Checklist of Odonata (Insecta) of Doon Valley, Uttarakhand, India

- Kritish De, Sarika Bhatt, Amar Paul Singh, Manisha Uniyal \& Virendra Prasad Uniyal, Pp. 20167-20173

Diversity of moths from the urban set-up of Valmiki Nagar, Chennai, India - Vikas Madhav Nagarajan, Rohith Srinivasan \& Mahathi Narayanaswamy, Pp. 20174-20189

Ichthyofaunal diversity with relation to environmental variables in the snowfed Tamor River of eastern Nepal

- Jawan Tumbahangfe, Jash Hang Limbu, Archana Prasad, Bhrarat Raj Subba \& Dil Kumar Limbu, Pp. 20190-20200

Observations on the foraging behavior of Tricoloured Munia Lonchura malacca (Linnaeus, 1766) and its interaction with pearl millet fields in Villupuram District, Tamil Nadu, India

- M. Pandian, Pp. 20201-20208

Roosting patterns of House Sparrow Passer domesticus Linn., 1758 (Aves: Passeridae) in Bhavnagar, Gujarat, India

- Foram P. Patel \& Pravinsang P. Dodia, Pp. 20209-20217

Review

Comprehensive checklist of algal class Chlorophyceae (sensu Fritsch, 1935) for Uttar Pradesh, India, with updated taxonomic status

- Sushma Verma, Kiran Toppo \& Sanjeeva Nayaka, Pp. 20218-20248

\section{View Point}

Wildlife managers ignore previous knowledge at great risk: the case of Rivaldo, the iconic wild Asian Elephant Elephas maximus L. of the Sigur Region, Nilgiri Biosphere Reserve, India

- Jean-Philippe Puyravaud \& Priya Davidar, Pp. 20249-20252

\section{Short Communications}

Diversity and distribution of macro lichens from Kalpetta Municipality of Wayanad District, Kerala, India

- Greeshma Balu, A.R. Rasmi, Stephen Sequeira \& Biju Haridas, Pp. 20253-20257

Extended distribution of two endemic epiphytes from the Western Ghats to the Deccan Plateau

- Sonali Vishnu Deore, Mangala Dala Sonawane \& Sharad Suresh Kambale, Pp. 20258-20260

Nomenclatural notes and report of Boehmeria penduliflora Wedd. ex D.G. Long from the Terai region of Uttar Pradesh, India

- Amit Gupta, Imtiyaz Ahmad Hurrah, Aparna Shukla \& Vijay V. Wagh, Pp. 2026120265
New distribution record of a true coral species, Psammocora contigua (Esper, 1794) from Gulf of Kachchh Marine National Park \& Sanctuary, India - R. Chandran, R. Senthil Kumaran, D.T. Vasavada, N.N. Joshi \& Osman G. Husen, Pp. 20266-20271

A new species of flat-headed mayfly Afronurus meenmutti (Ephemeroptera: Heptageniidae: Ecdyonurinae) from Kerala, India

- Marimuthu Muthukatturaja \& Chellaiah Balasubramanian, Pp. 20272-20277

Photographic record of Dholes predating on a young Banteng in southwestern Java, Indonesia

- Dede Aulia Rahman, Mochamad Syamsudin, Asep Yayus Firdaus, Herry Trisna Afriandi \& Anggodo, Pp. 20278-20283

Latrine site and its use pattern by Large Indian Civet Viverra zibetha Linnaeus, 1758: record from camera trap

- Bhuwan Singh Bist, Prashant Ghimire, Basant Sharma, Chiranjeevi Khanal \& Anoj Subedi, Pp. 20284-20287

Notes

Two additions to the flora of Kerala, India

- P. Murugan, Basil Paul \& M. Sulaiman, Pp. 20288-20291

Pentatropis R.Br. ex Wight \& Arn. (Apocynaceae), a new generic record for Kerala, India

- V. Ambika, Jose Sojan \& V. Suresh, Pp. 20292-20294

New record of Kashmir Birch Mouse Sicista concolor leathemi (Thomas, 1893) (Rodentia: Sminthidae) in the Indian Himalaya

- S.S. Talmale, Avtar Kaur Sidhu \& Uttam Saikia, Pp. 20295-20298

Breeding record of Black-headed Ibis Threskiornis melanocephalus (Aves: Threskiornithidae) at Mavoor wetland, Kozhikode District, Kerala, India - C.T. Shifa, Pp. 20299-20301

\section{Response}

Crop and property damage caused by Purple-faced Langurs Trachypithecus vetulus (Mammalia: Primates: Cercopithecidae) - Vincent Nijman, Pp. 20302-20306

Reply

If habitat heterogeneity is effective for conservation of butterflies in urban landscapes of Delhi, India? Unethical publication based on data manipulation: Response of original authors

- Monalisa Paul \& Aisha Sultana, Pp. 20307-20308

\section{Book Review}

Freshwater fishes of the Arabian Peninsula - Rajeev Raghavan, Pp. 20309-20310

Publisher \& Host

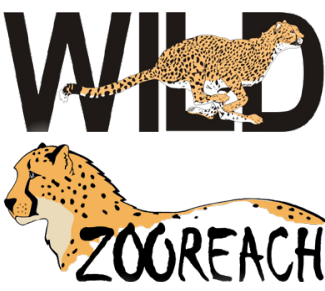

Threatened Taxa 